\title{
Thirty years of entrepreneurship research published in top journals: analysis of citations, co-citations and themes
}

\author{
Manuel P. Ferreira ${ }^{1,2^{*}}$, Nuno R. Reis ${ }^{3}$ and Rui Miranda ${ }^{3}$
}

\author{
* Correspondence: \\ manuel.portugal.ferreira@gmail.com \\ ${ }^{1}$ School of Technology and \\ Management, Polytechnic Institute \\ of Leiria, Leiria, Portugal \\ ${ }^{2}$ Graduate School of Management, \\ Universidade Nove de Julho, Av. \\ Francisco Matarazzo, 612, Prédio C - \\ 2º 05001-100 São Paulo, SP, Brazil \\ Full list of author information is \\ available at the end of the article
}

\begin{abstract}
Entrepreneurship research has increased markedly over the past three decades. In this paper we conduct a large scale survey of the literature beyond a subjective perspective on what entrepreneurship research has comprised. We investigate what have been the intellectual structure and the knowledge base underlying published entrepreneurship research. Moreover, we also conduct a longitudinal analysis of the main research themes that have caught scholars' efforts. Using bibliometric techniques on a sample of 1,777 articles published in 17 top ranked journals, between 1981 and 2010, we conduct analyses of citations, co-citations and co-occurrences to examine the most central works, themes and how they intertwine. Results provide evidence of the increasing interest in entrepreneurship as a field of study, but also of its interdisciplinary nature, with infusions of concepts and theories from a wide array of management disciplines. This paper provides a brief but extensive rear view of the field useful for both doctoral students and newcomers to the discipline develop their own research agendas.
\end{abstract}

Keywords: Bibliometric study; Entrepreneurship field; Literature review; Research trends

\section{Background}

Entrepreneurship research has evolved markedly over the past three decades and has grown from an embryonic and fragmented state (Shane and Venkataraman 2000; Busenitz et al. 2003; Zahra 2005; Schildt et al. 2006), with its legitimacy being questioned (Low and MacMillan, 1988), to a maturing field of study (Meyer et al. 2012; Busenitz et al. 2014; van Burg and Romme 2014). The increasing attention to new venture creation and innovation in small firms as drivers of economic growth, new educational programs in entrepreneurship and an increase in public policies supporting entrepreneurial endeavors has brought entrepreneurship to the forefront of a growing community of scholars' attention. Accompanying the increased scholarly attention, the number of dedicated outlets publishing entrepreneurship-related research has also risen and new journals have been created (e.g., Journal of Business Venturing, Entrepreneurship Theory and Practice and more recently Strategic Entrepreneurship Journal, among others) promoting the emancipation of the field (Busenitz et al., 2003).

(C) 2015 Ferreira et al. Open Access This article is distributed under the terms of the Creative Commons Attribution 4.0 International License (http://creativecommons.org/licenses/by/4.0/), which permits unrestricted use, distribution, and reproduction in any medium, provided you give appropriate credit to the original author(s) and the source, provide a link to the Creative Commons license, and indicate if changes were made. 
As entrepreneurship research accumulates it is important to periodically conduct different forms of literature reviews and bibliometric studies to grasp the accumulated knowledge (Busenitz et al. 2014; Ferreira et al. 2014). This involves identifying what has been made and what is already known, the streams and trajectories on the progression of entrepreneurship as a discipline (Zahra 2005; Schildt et al. 2006), as a departing point from which new arenas may be uncovered (Busenitz et al. 2014). Even if some attempts of understanding the current state of entrepreneurship research exist (e.g., Schildt et al. 2006; Teixeira, 2011; Campbell and Mitchell 2012; Busenitz et al. 2014), the field of entrepreneurship is still far from well mapped or understood. Therefore, it is useful to dissect what is known by looking into the stock of knowledge produced.

In this paper we seek to outline a broad description of the entrepreneurship field by identifying its main works and themes researched and how they are interconnected. We also aim at providing a brief outlook on the evolution by examining the research emphasis. In bibliometry we refer to the identification of the intellectual structure of the field and its knowledge base. To this aim, we conducted a bibliometric study of a large sample of articles published in 17 highly ranked journals on entrepreneurship or that publish entrepreneurship research over an extended period of time (1981 to 2010). In a sample of 1,777 articles, we conducted several bibliometric analyses. First, we described the track record of publications. Second, we performed an authorship analysis to identify the most prolific authors. Third, we analyzed citations and co-citations. Finally, we ascertained what were the most salient research themes in entrepreneurship during 1993 to 2010 and how the themes have evolved, by delving into the author-supplied keywords to proxy research themes.

This study contributes perhaps more especially to newcomers to the field and doctoral students, by putting forward a review of the literature, based on empirical bibliometric data, that provides a grasp of the past developments to the current state of development of the discipline. Equipped with the understanding of the accumulated knowledge, its core works, the intellectual structure and the knowledge base of the field (see also Landström et al. 2012) novel research agendas may be envisioned.

Hence, this study does not aim at prescribing how entrepreneurship research ought to develop, nor to propose what is the future of research in the field. We seek to gain a broad understanding of how the field has developed - or it's past. We are able to provide empirical evidence on the evolution of the field, its core works, themes delved into and conversations. We confirm prior studies noting the diversity of conceptual emphasis. These highlight what were the conceptual streams that have prevailed in the field. Hence we complement other bibliometric studies and literature reviews that targeted specific aspects by adopting a longer timespan, a larger number of journals and articles, and a different set of analyses. For instance, Ratnatunga and Romano (1997) conducted a citation analysis of the articles published on small enterprise research. Shane (2000) studied scholars and universities that publish on entrepreneurship. Cornelius et al. (2006) examined the research fronts in entrepreneurship and Schildt et al. (2006) identified the research communities. Meyer et al. (2012) examined the main clusters of researched assessed by coding the keywords and titles of the articles to find five clusters. Busenitz et al. (2014) delved into ten years of research (2000-2009) and classified entrepreneurship research in four groups observing a modest increase in opportunitiesdriven studies. Alvarez et al. (2012) focused on examining research based on the Global Entrepreneurship Monitor (GEM) report, finding that institutional theory has become a 
major conceptual framework. And Jing et al. (2014) contrasted entrepreneurship research in the US, Europe and China, identifying differences in the paths followed. Hence, albeit other bibliometric studies in entrepreneurship exist, we are unaware of any study following a similar approach, with a large dataset, an extended period of time, comprising structural and longitudinal analyses and delving both on the intellectual structure and the knowledge base of the field.

\section{The field of entrepreneurship}

Early research on entrepreneurship may be traced back to the first half of the $20^{\text {th }}$ century, and to works such as those by Knight (1921) and Schumpeter (1934) but has much increased since then. There have been some attempts to make sense of the extant entrepreneurship research and foresee future research trends. The first effort to unify and advance research dates to the 1980s with the Encyclopedia of Entrepreneurship (Kent et al., 1982) and the review of multiple aspects of entrepreneurship, ranging from psychological and social perspectives to the economic effects, and future directions for research, teaching and practice. Churchill and Lewis (1986) analyzed the articles published between 1981 and 1984 to classify entrepreneurship research according to the objectives, methodologies and topics. Low and MacMillan (1988) used a six items research design specification to understand how entrepreneurship had been studied thus far: purpose, theoretical perspective, focus, level of analysis, time frame and methodology. Low and Macmillan (1988) acknowledged the shortcomings of entrepreneurship research and called for theory-driven research. Later, Shane and Venkataraman (2000) advanced the three main pillars of entrepreneurship research: the opportunities (including the sources, discovery, assessment and exploitation) and the entrepreneurs (the individuals which seek, discover, assess and exploit the opportunities), positing research should be developed along these avenues.

More recently, a number of scholars have reviewed extant research to take stock of what is known, observing the fragmentation of the field (e.g., van Burg et al. 2013). The entrepreneurship field is posited to have permeable boundaries which hinder the legitimation of the field (Busenitz et al. 2003) despite being an increasingly autonomous discipline (Teixeira 2011). Nevertheless, entrepreneurship research denotes a strong influence of theoretical approaches borrowed from other social sciences (Landström et al. 2012). Literature reviews have also revealed a substantial growth in the number of papers published in the last decade as well as the dominance of Anglo-Saxon researchers (Landström et al. 2012). Notwithstanding, European and Chinese scholars are becoming increasingly interested in entrepreneurship research and take advantage of local idiosyncrasies in their research (Jing et al. 2014).

While an overview of major research streams is not needed, we point here just a few of the core streams of thought that have permeated entrepreneurship studies. Entrepreneurship research analyzes a wide range of topics and phenomena, ranging from the antecedents to the outcomes and the entrepreneurship process. For instance, entrepreneurial opportunities have been delved into from a number of perspectives (Busenitz et al. 2003; Busenitz et al. 2014). The issues of opportunity perception - either creating, identifying or recognizing - and opportunity exploitation - including the evaluation of opportunity - have warranted scholars' research attention (van Burg et al. 2013). Some studies go beyond perception and exploitation to assess the outcomes of opportunities (van Burg et al. 2013). Other approaches include the individual perception of 
opportunities which place a particular emphasis on knowledge and prior experience (Short et al. 2010). Although we may identify classical works which emphasize opportunities as the core of entrepreneurial activity (e.g., Kirzner 1973), opportunities have once been considered "the most neglected question in the entrepreneurship literature" (Venkataraman 1997, p. 122). However the situation has changed and we may observe a modest increase for instance in opportunities-related research (for a detailed analysis, please see Busenitz et al., 2014).

The early stages of entrepreneurship were also analyzed, especially the "nascent entrepreneurship" stages (Bergmann et al. 2013). The nascent entrepreneurs are those still struggling to start their venture or whose business is still not fully operational (Reynolds 2005). Ascertaining the key challenges and outcomes of nascent entrepreneurs, their success and especially what drives an individual to start a new venture are some of the questions this stream of research has sought to examine (Reynolds 2005; Bergmann et al. 2013).

Another stream of research has focused on the entrepreneurial networks, often conceptually supported on social networks theory but perhaps more notably taking the more practitioners view of examining how entrepreneurial activity is propelled by the individuals' social networks, which are in essence different from non-entrepreneurial networks (Granovetter 1985), and the value of the entrepreneurs' networks for the initial stages of the firms' life cycle. The networks have been shown to be crucial for accessing knowledge (e.g., opportunity recognition) and a variety of resources (financial, technical, physical, informational, reputation) and are thus crucial to the success of the new venture. This approach shares some ties to the resource-based and knowledgebased views (Alvarez and Busenitz 2001).

Corporate entrepreneurship (see, for instance, Zahra and Covin 1995) - or intrapreneurship, as coined by Pinchot in the late 1970s - is yet another relevant stream of thought. Intrapreneurship may be defined as proactively innovating by introducing new processes and developing new processes and venturing into new businesses to create shareholder value, is deemed vital for established firms to survive and revitalize (Pinchot, 1985; Zahra and Covin 1995). Analyzing entrepreneurship at the level of the firm arguably allows for a better understanding of the value creation process and it is possible to grasp corporate entrepreneurship contribution to firms' capabilities and competencies (Alvarez and Busenitz 2001).

Entrepreneurship has also been delved into from an international business perspective (McDougall and Oviatt 2000; Oviatt and McDougall, 2005; Schildt et al. 2006). International entrepreneurship scholars have focused specifically on the "combination of innovative, proactive and risk-seeking behavior that crosses national borders and is intended to create value in organizations" (McDougall and Oviatt 2000, p. 903). In fact, international entrepreneurship research is strongly influenced by the born global phenomenon - those firms which "from inception, [seek] to derive significant competitive advantage from the use of resources and the sale of outputs in multiple countries" (Oviatt and McDougall 1994, p. 49).

Finally, a stream of research has analyzed the effects of the entrepreneurial activity on the external environment. Arguably one of the first systematic attempts was Wilken's (1979) model to describe a causal relation between entrepreneurship and economic growth. Entrepreneurship is posited to have an important impact on job 
creation (e.g., Birch, 1987) and this claim became conventional wisdom to the point of influencing policy making (Neumark et al., 2011). Beyond job creation, entrepreneurship is posited to have an effect on knowledge spillovers and consequently on wealth creation (Audretsch and Feldman 1996). Thus entrepreneurship is posited to have a significant impact on economic growth, including on regional and national policy studies (e.g., Audretsch and Feldman 1996).

\section{Methods}

Bibliometric studies rely on the measurement of scientific activity employing statistical procedures (Broadus, 1987) to quantify, classify and organize the extant research in a field (White \& McCain, 1998). The main advantage of bibliometry compared to other methods is that it permits a largely unbiased view of a field of study, that other forms of literature reviews may bring (Garfield, 1979). And, although there is no single technique for conducting a bibliometric study, the most common procedures involve examining citations, co-citations and co-occurrences of keywords.

\section{Data and sample}

The procedures to identify the sample involved three stages. The first stage comprised of selecting the journals. We selected journals following a set of criteria: the high ranked journals using Ann-Will Harzing's 'Journal quality list' (2011), ISI and Scopus impact factors, and also the selection of journals in prior bibliometric studies (e.g., Schildt et al. 2006; Landström et al. 2012; Álvarez et al. 2012; Busenitz et al. 2014, Jing et al. 2014). We selected 17 journals, both generalist in management and dedicated entrepreneurship journals which are indexed in ISI web of knowledge. It is worth noting that we included Strategic Entrepreneurship JournaI (SEJ) that albeit a recent journal (founded in 2007) with a short track record already has an ISI 5-year impact factor of 2, denoting that it will likely grow to a core outlet in the field.

The second stage required defining the time frame of the analysis. To encapsulate a large portion of the research to conduct longitudinal analysis we selected 1981 to 2010. The initial year is somewhat arbitrary but we noted that up to the beginning of the nineties there were relatively few articles. According to Meyer et al. (2012) the field grew during the 1990s and reached a maturing state in the 00s. Moreover, this timespan is ten years longer than the recent review by Busenitz et al. (2014).

The third stage in building the sample comprised using ISI Web of Knowledge, and the search engine Web of Science to identify the articles. This database has been used in many prior bibliometric studies (Schildt et al. 2006; Furrer et al. 2008; Meyer et al. 2012; Ferreira et al. 2014; Busenitz et al. 2014) and holds greater prestige than alternatives such as Scopus. In searching the database we used the search terms (or keywords) of Busenitz et al. (2003): entrepreneur*, entrepreneurial", entrepreneurship*, small business, new ventures and founders. The asterisk permits capturing other variations of the wording. Meyer et al. (2012) for instance, used only a truncated form: "entrep". Finally, we manually screened all articles by reading at least the title or abstract and keywords.

Using these procedures we had a final sample of 1,777 articles, with the largest contributors being dedicated entrepreneurship journals - Journal of Business Venturing $(n=413)$, Small Business Economics $(n=326)$, Journal of Small Business Management $(n=192)$, 
Entrepreneurship Theory \& Practice $(n=177)$-, although also with a significant contribution from the Strategic Management Journal $(n=88)$ (see Table 4 in Appendix).

\section{Procedures of analyses}

In examining the data we performed three types of analyses: citations, co-citations and co-occurrences. These procedures permit identifying the structure binding works (and theories) and themes researched.

\section{Citation analysis}

Citation analyses rely on counting the number of times any given work is referenced by other scholars in their own works, and thus assess its impact, or influence, in the community (White and McCain, 1998). Citing prior works is a crucial norm in scientific endeavors based on the rationale that scholars cite other works that are relevant to their own research. Albeit citations may be made with a variety of purposes, it is a common practice, although not free from known criticisms (e.g., Bornmann and Daniel 2008), the use of citation data to assess a scholar's impact on a given discipline or field (Culnan 1987; Tahai and Meyer 1999).

\section{Co-citation analysis}

A co-citation analysis examines pairs of works and assesses the frequency with which they are cited together, or co-cited, in other works (Culnan 1987). Moreover, cocitation analyses are based on the premise that if a given pair of works is co-cited it is because they share some content, or intellectual, similarity (White and Griffith 1981; White and McCain 1998; Ponzi 2002; Ferreira et al. 2014). For instance, if two articles $\mathrm{X}$ and $\mathrm{Y}$ were cited by another article we may reasonably assume that $\mathrm{X}$ and $\mathrm{Y}$ are somewhat related. Thus, the more frequently a set of papers is co-cited in the extant research the stronger is the tie binding them and the more proximate they are (White and McCain 1998). Thus, co-citation analyses allow researchers to understand the structure of the social networks in a more objective manner than would possible in other forms of literature reviews. We depict the co-citation matrixes visually in a network to reveal the social structure of the field.

\section{Analysis of the research themes}

The third procedure entailed examining the themes, or phenomena, researched over the period and their relative centrality in the discipline. Usually such analysis would entail a content analysis, possibly subjective, which is unviable using a sample of 1,777 articles. To this aim we followed the procedure of Furrer et al. (2008) method for inferring research themes from the author-supplied keywords by grouping the author-supplied keywords into broader categories. We designed a list of 25 major research themes based on Schildt et al. (2006) identification of the main themes in entrepreneurship studies (see Table 5 in Appendix - complete coding available from the authors upon request). Schildt et al. (2006) list has the advantage of being inclusive of the major themes in entrepreneurship research. Perhaps using the authorsupplied keywords is a rather stringent manner to observe themes, but it is reasonable to suggest that it is an accurate manner since the authors select the keywords to best describe what their paper is about to potential readers and for indexing purposes. 
This procedure involved, first, retrieving the author-supplied keywords from all articles in the sample. We obtained a total of 3,880 keywords (it is worth noting that this analysis was conducted for the period 1991 to 2010 since ISI Web of Knowledge does not contain the keywords for articles published prior to 1991). Then, two coders (full time graduate research assistants) were given instructions and were asked to independently allocate each keyword to each of the 25 broad themes. Jointly, the sample included 3,880 keywords. Any discrepancies were resolved between the coders and the assistance of the principal investigator. Methodologically, in Bibexcel the author-supplied keywords were replaced by the themes and a new co-occurrence matrix was generated for running a social network analysis.

All data was retrieved from SSCI ISI WoK and organized using the software Bibexcel (available at www.umu.se/inforsk/Bibexcel), and we used the social networks software Ucinet to draw the visual network displays. These maps are based on the matrixes of co-citations of references and of co-occurrences of keywords. The visual displays are intended to facilitate the identification and interpretation of the structure underlying a group of works.

\section{Results}

The analyses of the data follow the sequence: evolution of publication and geographic origin, citations analysis, co-citations, and the main research themes.

\section{Evolution of entrepreneurship research}

There has been a clear upward trend in the number of publications in entrepreneurship (Fig. 1), as assessed by the number of articles published. A sharp increase around 1991 was followed by a second surge in 2002, but over $50 \%$ of the articles were published in the last 6 years, between 2005 and 2010. This trend has been fuelled by the founding of new outlets, research centers, masters and doctoral studies on entrepreneurship, and the ability of entrepreneurship scholars to take their works into the top tier management journals. The founding of new journals is a signal that the discipline is maturing (van Burg et al. 2013) and gaining status in management research (Busenitz et al. 2014). It is worth noting that four of the journals were relatively recently included in SSCI, even if some

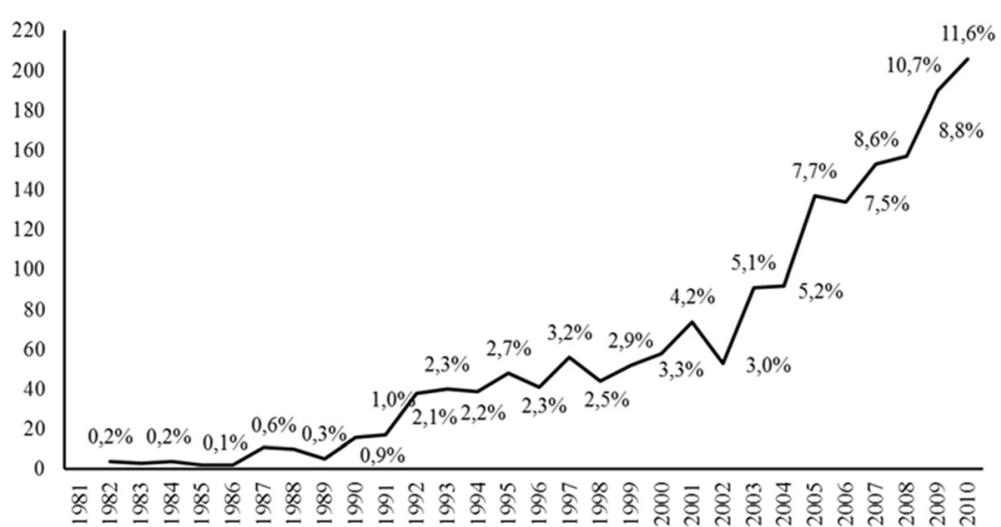

Fig. 1 Evolution of publications (articles per year): 1981-2010. Source: Data collected from ISI Web of Knowledge. Computations by the authors 
are much older: Entrepreneurship and Regional Development (2001), Entrepreneurship Theory and Practice (2003), International Small Business Journal (2003) and Strategic Entrepreneurship Journal (2007).

The articles in the sample were (co)authored by 2,290 scholars from 63 nations. Three countries account for $66 \%$ of all authors: the US (44.7 \%), UK (304 authors, $13.3 \%$ ) and Canada (181, $7.9 \%)$. Noteworthy is the absence, or under-representation, of emerging economies, such as India (7 articles), Mexico (1), and Brazil (0), where entrepreneurship research has made substantial progress, and of the majority of African countries. A possible explanation may reside in the difficulties in non-English speaking countries in writing an article in English at a level of quality warranted by the outlets sampled.

\section{Most influential works}

Table 1 identifies the 30 most influential, or most cited, works in our sample. Schumpeter's (1934) seminal work - The theory of economic development - with his thoughts on the role of the entrepreneur in driving innovations is the most cited (235 citations). A number of the works in the table debate what is the field of entrepreneurship, its domain and raison d'être, defining and establishing the boundaries of the field (Gartner 1985; Lumpkin and Dess 1996; Venkataraman 1997; Shane and Venkataraman 2000). Other works review the existing literature (e.g., Low and Macmillan 1988). We may also observe a significant number of works on the role of the entrepreneur in starting new ventures (Knight 1921; Kirzner 1973; Evans and Jovanovic 1989; Vesper 1990; Burt 1992; Aldrich 1999; Shane 2000) and others focusing opportunities (Kirzner 1973; Venkataraman 1997; Shane 2000).

This data is further revealing of the diverse theoretical background, or multidisciplinarity, of entrepreneurship studies: Resource-Based View (Penrose 1959; Barney 1991), Social networks (Granovetter 1985; Burt 1992), Agency theory (Jensen and Meckling 1976), Learning (Nelson and Winter 1982; Cohen and Levinthal 1990), Resource dependence (Pfeffer and Salancik 1978). Interestingly, other works with high impact are revealing of methodological concerns, such as Eisenhardt (1989) on case studies, and Nunnally (1978) on statistical procedures and details.

We further conducted a longitudinal citation analysis (Table 2) to observe possible shifts of research over time and to grasp the influence of different works and theories over time. Table 2 reveals the data in four periods: 1981-1990, 1991-2000, 2001-2005 and 2006-2010. Having shorter periods in more recent years permits better observing shifts and seems appropriate given the upward trend in publications especially from the 1990s onwards. Observing Table 2, we identify some evolution in the most influential works, and the citation counts are a reflection of the contexts and theories that were more salient during the periods. For instance, in the first period (1981-1990) we see the impact of early approaches to entrepreneurship (such as Schumpeter 1934; Brockhaus 1982; Vesper 1990), and an important representation of classical strategic managementrelated works (e.g., Chandler, 1962; Miles and Snow 1978; Mintzberg 1979; Porter 1980). Over time we perceive an increasing influence of entrepreneurship-specific works (such as Kirzner 1973; Low and MacMillan 1988; Lumpkin and Dess 1996; Venkataraman 1997; Shane and Venkataraman 2000; Shane 2000). This is a signal of the maturing of the field as it finds its distinctive raison d'être. 
Table 1 Top 30 most cited works

\begin{tabular}{|c|c|c|c|}
\hline Reference & Citations & Title & About \\
\hline Schumpeter (1934) & 235 & The theory of economic development & Classical analysis of the capitalist society emphasizing the role of the entrepreneur as an innovator. \\
\hline $\begin{array}{l}\text { Shane and Venkataraman } \\
\text { (2000) }\end{array}$ & 207 & $\begin{array}{l}\text { The promise of entrepreneurship as a } \\
\text { field of research }\end{array}$ & Put forward a framework for entrepreneurship and focused extensively on entrepreneurial opportunities. \\
\hline Stinchcombe (1965) & 163 & Social structure and organizations & $\begin{array}{l}\text { Scrutinized the interaction between organizations and the external environment, conceptualizing organizations as } \\
\text { an open systems. }\end{array}$ \\
\hline Barney (1991) & 156 & $\begin{array}{l}\text { Firm resources and sustained competitive } \\
\text { advantage }\end{array}$ & Seminal work on the RBV, put forth the conditions firms' resources must hold to produce sustained competitive advantage. \\
\hline Porter (1980) & 140 & Competitive strategy & $\begin{array}{l}\text { Using an industrial organization approach, advanced two notorious frameworks: the five forces model of } \\
\text { competition and the taxonomy of generic competitive strategies. }\end{array}$ \\
\hline Penrose (1959) & 129 & The theory of the growth of the firm & One of the first works to focus the firm's resources as drivers of success and growth that has laid the foundations for RBV. \\
\hline Kirzner (1973) & 122 & Competition and entrepreneurship & $\begin{array}{l}\text { Focused on the role of entrepreneurs as drivers of market process since they detect unnoticed profit opportunities } \\
\text { and thus influence price setting. }\end{array}$ \\
\hline Venkataraman (1997) & 119 & $\begin{array}{l}\text { The distinctive domain of } \\
\text { entrepreneurship research }\end{array}$ & $\begin{array}{l}\text { Set the boundaries of the entrepreneurship field and positions the opportunity at the core of entrepreneurship } \\
\text { research. }\end{array}$ \\
\hline Nelson and Winter (1982) & 114 & $\begin{array}{l}\text { An evolutionary theory of economic } \\
\text { change }\end{array}$ & Developed of an evolutionary theory of business behavior, borrowing natural selection concepts from Biology. \\
\hline Schumpeter (1942) & 109 & Capitalism, socialism and democracy & $\begin{array}{l}\text { Delved on different economic and political systems and advances the "creative destruction process" and the central } \\
\text { role of entrepreneurs. }\end{array}$ \\
\hline Granovetter (1985) & 107 & $\begin{array}{l}\text { Economic action and social structure: The } \\
\text { problem of embeddedness }\end{array}$ & Addressed the embeddedness of organizations economic actions in a wider context of social relations. \\
\hline Eisenhardt (1989) & 105 & $\begin{array}{l}\text { Building theories from case study } \\
\text { research }\end{array}$ & $\begin{array}{l}\text { Described the process of using case studies to induct theory, a method appropriate in new fields. It has become a } \\
\text { core reference for qualitative research using case studies. }\end{array}$ \\
\hline Pfeffer and Salancik (1978) & 103 & $\begin{array}{l}\text { The external control of organizations: A } \\
\text { resource dependence perspective }\end{array}$ & $\begin{array}{l}\text { Focused on the influence of the external environment on organizations noting that organizations need a variety of } \\
\text { resources to survive and prosper. }\end{array}$ \\
\hline Low and MacMillan (1988) & 103 & $\begin{array}{l}\text { Entrepreneurship: Past research and } \\
\text { future challenges }\end{array}$ & $\begin{array}{l}\text { A review and definition of entrepreneurship as a field, analyzing the contributions and challenges ahead at several } \\
\text { levels. }\end{array}$ \\
\hline Busenitz and Barney (1997) & 101 & $\begin{array}{l}\text { Differences between entrepreneurs and } \\
\text { managers in large organizations: Biases } \\
\text { and heuristics in strategic decision-making }\end{array}$ & Explored the differences between managers and entrepreneurs at the decision-making process level. \\
\hline
\end{tabular}


Table 1 Top 30 most cited works (Continued)

\begin{tabular}{|c|c|c|c|}
\hline Shane (2000) & 101 & $\begin{array}{l}\text { Prior knowledge and the discovery of } \\
\text { entrepreneurial opportunities }\end{array}$ & Addressed the importance of the information individuals' hold in discovering entrepreneurial opportunities. \\
\hline Cohen and Levinthal (1990) & 101 & $\begin{array}{l}\text { Absorptive capacity: A new perspective } \\
\text { on learning and innovation }\end{array}$ & $\begin{array}{l}\text { Put forward the concept of absorptive capacity, or the ability to learn and recognize new information and use it } \\
\text { commercially. }\end{array}$ \\
\hline Lumpkin and Dess (1996) & 101 & $\begin{array}{l}\text { Clarifying the entrepreneurial orientation } \\
\text { construct and linking it to performance }\end{array}$ & Addressed the relation between entrepreneurial orientation and firm performance using a contingency framework. \\
\hline Aldrich (1999) & 100 & Organizations evolving & $\begin{array}{l}\text { Reviewed and advanced an evolutionary theory of organizations addressing the role of the entrepreneur in creating } \\
\text { organizations. }\end{array}$ \\
\hline Gartner (1985) & 98 & $\begin{array}{l}\text { A conceptual framework for describing } \\
\text { the phenomenon of new venture } \\
\text { creation }\end{array}$ & $\begin{array}{l}\text { Advanced an encompassing framework for new ventures integrating individual-, organization-, environment- and } \\
\text { process-level characteristics. }\end{array}$ \\
\hline Knight (1921) & 98 & Risk, uncertainty and profit & Focused the vital role of the entrepreneur in profit making activities as agents who face uncertainty. \\
\hline Burt (1992) & 96 & $\begin{array}{l}\text { Structural holes: The social structure of } \\
\text { competition }\end{array}$ & $\begin{array}{l}\text { Drawing on social networks theory focused the entrepreneur as the link between two individuals with } \\
\text { complementary resources. }\end{array}$ \\
\hline Nunnally (1978) & 93 & Psychometric theory & Addressed methodological issues of psychological measurement when investigating individual characteristics. \\
\hline Storey (1994) & 92 & Understanding the small business sector & Analyzed the idiosyncrasies of small firms and addresses the role of entrepreneurship in small businesses. \\
\hline Cyert and March (1963) & 92 & Behavioral theory of the firm & $\begin{array}{l}\text { Used a behavioral approach and posits decision-makers are not absolutely rational and do not have perfect } \\
\text { information. }\end{array}$ \\
\hline Jensen and Meckling (1976) & 90 & $\begin{array}{l}\text { Theory of the firm: Managerial behavior, } \\
\text { agency costs and ownership structure }\end{array}$ & Developed a theory for firms' ownership drawing on agency theory. \\
\hline Miller (1983) & 90 & $\begin{array}{l}\text { The correlates of entrepreneurship in } \\
\text { three types of firms }\end{array}$ & Analyzed the determinants of entrepreneurship in different types of firms. \\
\hline Evans and Jovanovic (1989) & 85 & $\begin{array}{l}\text { An estimated model of entrepreneurial } \\
\text { choice under liquidity constraints }\end{array}$ & $\begin{array}{l}\text { Investigated the liquidity necessities to become entrepreneur and concluded people with insufficient funds do not } \\
\text { start new businesses. }\end{array}$ \\
\hline Vesper (1990) & 85 & New venture strategies & Tackled the different forms of entering a new business, both from an individual and firm perspective. \\
\hline Covin and Slevin (1989) & 83 & $\begin{array}{l}\text { Strategic management of small firms in } \\
\text { hostile and benign environments }\end{array}$ & Examined several strategic aspects of small firms focusing on the importance of the external environment. \\
\hline
\end{tabular}

Source: data collected from ISI - Web of Knowledge. Computations by the authors 
Table 2 Top 30 most cited works per period

\begin{tabular}{|c|c|c|c|c|c|c|c|c|}
\hline \multicolumn{2}{|l|}{$1981-1990(n=60)$} & \multicolumn{2}{|l|}{$1991-2000(n=431)$} & \multicolumn{2}{|l|}{$2001-2005(n=447)$} & \multicolumn{2}{|l|}{$2006-2010(n=839)$} & \\
\hline Reference & Cit & Reference & Cit & Reference & Cit & Reference & Cit & \\
\hline Porter (1980) & 12 & Schumpeter (1934) & 55 & Schumpeter (1934) & 64 & Shane and Venkataraman (2000) & 150 & $\approx$ \\
\hline Vesper (1990) & 10 & Porter (1980) & 54 & Shane and Venkataraman (2000) & 56 & Schumpeter (1934) & 108 & $\approx$ \\
\hline Brockhaus (1982) & 9 & Low and MacMillan (1988) & 43 & Barney (1991) & 53 & Stinchcombe (1965) & 88 & $\approx$ \\
\hline Hornaday and Aboud (1971) & 9 & Vesper (1990) & 36 & Penrose (1959) & 42 & Barney (1991) & 83 & $\approx$ \\
\hline McClelland (1961) & 8 & Stinchcombe (1965) & 35 & Stinchcombe (1965) & 40 & Shane (2000) & 79 & $\nearrow$ \\
\hline Carland et al. (1984) & 8 & McClelland (1961) & 27 & Lumpkin and Dess (1996) & 37 & Venkataraman (1997) & 79 & $\approx$ \\
\hline Miller and Friesen (1982) & 8 & Covin and Slevin (1989) & 26 & Venkataraman (1997) & 36 & Aldrich (1999) & 72 & $\nearrow$ \\
\hline Collins and Moore (1964) & 8 & Nunnally (1978) & 26 & Busenitz and Barney (1997) & 35 & Penrose (1959) & 67 & $\searrow$ \\
\hline Schumpeter (1934) & 8 & Gartner (1985) & 25 & Granovetter (1985) & 35 & Eisenhardt (1989) & 66 & $\nearrow$ \\
\hline Miller (1983) & 8 & Williamson (1985) & 25 & Storey (1994) & 35 & Kirzner (1973) & 66 & $\approx$ \\
\hline Brockhaus (1980) & 8 & Porter (1985) & 23 & Porter (1980) & 33 & Nelson and Winter (1982) & 65 & $\nearrow$ \\
\hline Drucker (1985) & 7 & Sandberg and Hofer (1987) & 23 & Kirzner (1973) & 33 & Knight (1921) & 61 & $\nearrow$ \\
\hline Williamson (1975) & 7 & Kanter (1983) & 23 & Cohen and Levinthal (1990) & 32 & Busenitz and Barney (1997) & 59 & $\searrow$ \\
\hline Chandler (1962) & 7 & Miller (1983) & 23 & Cooper et al. (1994) & 31 & Pfeffer and Salancik (1978) & 59 & $\nearrow$ \\
\hline Burns and Stalker (1961) & 7 & Williamson (1975) & 22 & Schumpeter (1942) & 31 & Burt (1992) & 58 & $\nearrow$ \\
\hline Mintzberg (1979) & 7 & Jovanovic (1982) & 22 & Low and MacMillan (1988) & 30 & Schumpeter (1942) & 58 & $\approx$ \\
\hline Miles and Snow (1978) & 7 & Brockhaus (1980) & 21 & Jensen and Meckling (1976) & 29 & Cohen and Levinthal (1990) & 57 & $\nearrow$ \\
\hline Mintzberg (1973) & 7 & Timmons (1994) & 21 & Granovetter (1973) & 29 & Granovetter (1985) & 55 & $\nearrow$ \\
\hline Kanter (1983) & 6 & Carland et al. (1984) & 21 & Eisenhardt (1989) & 29 & Stuart et al. (1999) & 54 & $\nearrow$ \\
\hline Liles (1974) & 5 & Macmillan et al. (1985) & 20 & Burt (1992) & 28 & Sarasvathy (2001) & 53 & $\nearrow$ \\
\hline Thompson (1967) & 5 & Kirzner (1973) & 20 & Birley (1987) & 28 & March (1991) & 51 & $\nearrow$ \\
\hline Collins and Moore (1970) & 5 & Nelson and Winter (1982) & 20 & Aldrich (1999) & 28 & Lumpkin and Dess (1996) & 50 & $\nearrow$ \\
\hline Churchill and Lewis (1983) & 5 & Hannan and Freeman (1989) & 20 & Eisenhardt and Schoonhoven (1990) & 28 & Aldrich and Fiol (1994) & 49 & $\nearrow$ \\
\hline
\end{tabular}


Table 2 Top 30 most cited works per period (Continued)

\begin{tabular}{|c|c|c|c|c|c|c|c|c|}
\hline Burgelman (1983) & 5 & Barney (1991) & 20 & Nelson and Winter (1982) & 27 & Scott (1995) & 49 & $\nearrow$ \\
\hline Smith (1967) & 5 & Van de Ven et al. (1984) & 20 & Evans and Jovanovic (1989) & 27 & Davidsson and Honig (2003) & 48 & \\
\hline Von Hippel (1977) & 4 & Evans and Jovanovic (1989) & 20 & Cyert and March (1963) & 27 & Kirzner (1997) & 47 & \\
\hline Smith and Miner (1983) & 4 & Weick (1979) & 19 & Pfeffer and Salancik (1978) & 25 & Shane (2003) & 47 & \\
\hline Peters (1982) & 4 & Cyert and March (1963) & 19 & Miller (1983) & 24 & Gimeno et al. (1997) & 47 & \\
\hline MacMillan and Day (1987) & 4 & Brockhaus (1982) & 19 & Nunnally (1978) & 24 & Gartner (1985) & 47 & $=$ \\
\hline Nunnally (1978) & 4 & Jensen and Meckling (1976) & 18 & Gartner (1985) & 23 & North (1990) & 45 & \\
\hline
\end{tabular}

Note: Cit - number of citations

Source: data collected from ISI Web of Knowledge. Computations by the authors 
From a theoretic standpoint, the evolution revealed in Table 2, shows an increase in the influence of theories of the firm (e.g., Cyert and March 1963; Williamson, 1975; Porter 1980; Nelson and Winter 1982) and a decrease in the influence of psychologyrelated theories (e.g., McClelland 1961). Moreover, the more recent periods have a strong influence of resource- (e.g., Penrose 1959; Barney 1991; Busenitz and Barney 1997) and capabilities-related references (Cohen and Levinthal 1990; Eisenhardt and Schoonhoven 1990). That is, after the 1990s - after Barney's (1991) article - more entrepreneurship research started incorporating RBV lenses thus focusing on the pool of resources, competences and capabilities of the new ventures. Hence, a longitudinal examination of the citations frequencies unveils some relevant shifts.

\section{Intellectual structure of the field}

The intellectual structure of a field may be depicted visually in a co-citation network (White and Griffith, 1981; White and McCain, 1998). In drawing the network we selected only the 30 works more often cited, from a list of more than 50,000 works cited, since a larger number would not render an intelligible figure. In reading the figure note that, first, the ties linking works represent a co-citation between a pair of authors, and the thicker the ties the more frequently two works are co-cited. Second, the size of the circle reflects citation frequency. Moreover, the software is dynamic and places at the center of the network the works that are more cited. Similarly, the pairs of works will be placed more proximate or more apart according to the co-citation frequency.

Figure 2 shows at the core, thus bearing greater impact, Schumpeter's (1934) work, in close proximity with Kirzner (1973) on entrepreneurship and competitiveness, and Shane and Venkataraman (2000) on entrepreneurial opportunities. This relative proximity signifies a strong research emphasis on the entrepreneur as the innovator who identifies opportunities to make a profit. Barney (1991) and Penrose (1959) are also central, indicating that resource- and capabilities-based explanations have been frequent. The network comprises several other seminal works and although those works positioned in the outer layers are important, they matter relatively less for the overall set of works. Finally, the various theoretical perspectives may be perceived as a sign of the youth of the discipline (Shane and Venkataraman 2000; van Burg \& Romme, 2014).

\section{Main research themes}

Finally, we examined the themes that entrepreneurship researchers have studied. Figure 3 displays the network binding themes and their relative centrality. At the center of the network are the five most often studied themes: "Entrepreneurial process", "Environmental and external determinants of entrepreneurship", "Value creation and performance" and "Methods, theories and research issues".

Other themes have also been relevant, such as "Psychological, cognitive and individual characteristics", "Entrepreneurial resources", "Entrepreneurial networks", "High-tech entrepreneurship", "Corporate venturing and business competition", and "Entry modes, international, born-global and MNE" but are positioned in a second ring. In the outer layer, signaling less emphasis, are such themes as "Entrepreneurial opportunity", "Entrepreneurial family business", and "Human resource management". 

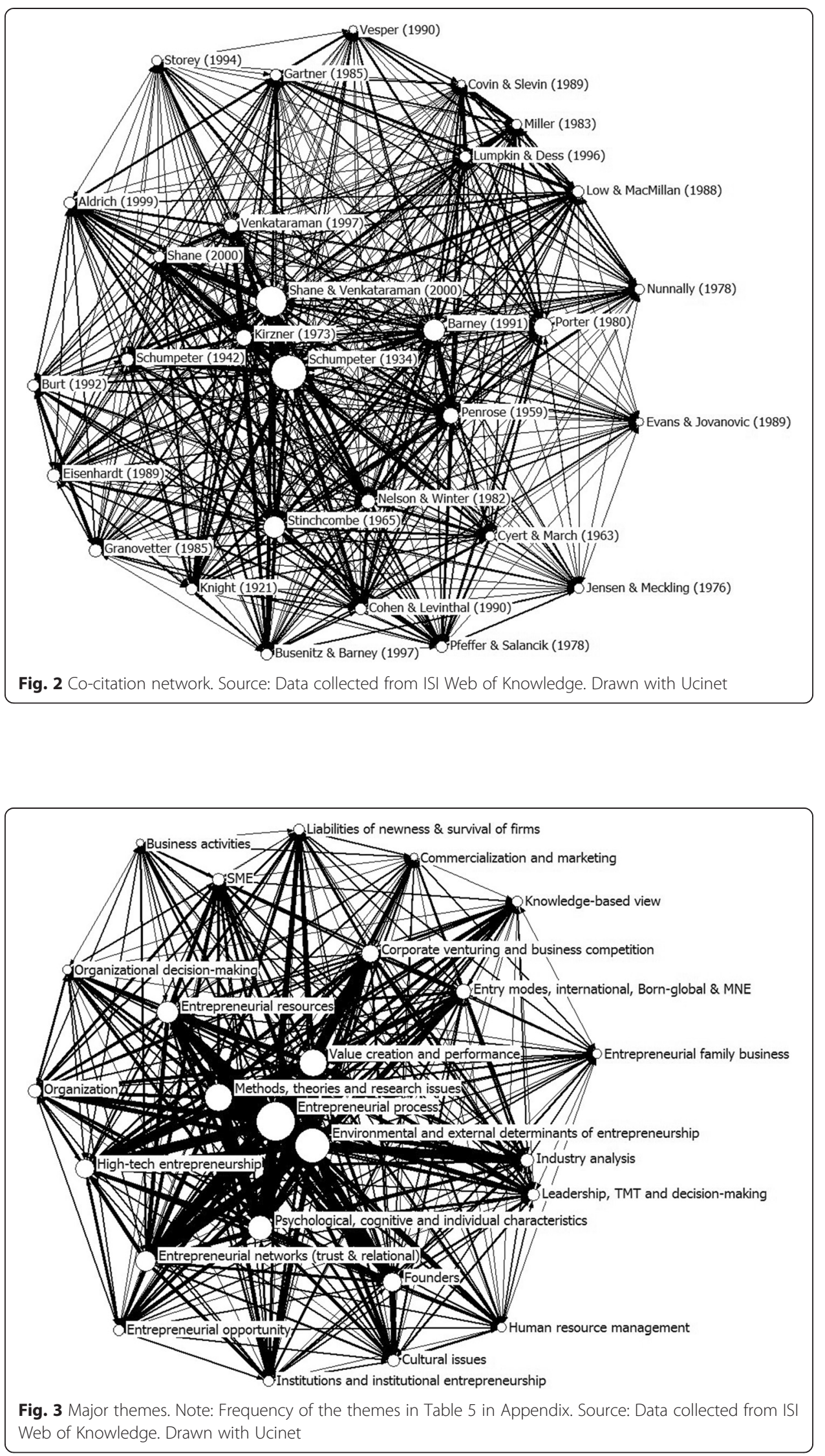


\section{Longitudinal perspective on the research themes}

To assess possible shifts in scholars' emphasis, we conducted a longitudinal analysis on the themes for three periods: 1991-2000, 2001-2005 and 2006-2010. Table 3 depicts the most frequent ten themes for each period. The shifts are substantial albeit some themes have received constant interest, such as the "Entrepreneurial process", "Environmental determinants of entrepreneurship" and, on a second tier, also "High-tech entrepreneurship", probably accompanying the success of technology-based start-ups since the 1990s.

Methodological and theoretical issues were also central in the past two decades possibly reflecting the maturing of the field and a concern with more accurate empirical studies. The attention to methodological aspects is revealing of the effort to move the discipline beyond descriptive and case study-based approaches that marked its beginning. We may also observe an increase in research dealing with "Psychological, cognitive and individual characteristics" of entrepreneurs suggesting an interest on the individual processes of detecting and exploiting opportunities. On the other hand, "Corporate venturing" and "Industry analysis" have lost comparative importance in entrepreneurship research.

This analysis is also important in identifying the topics that were comparatively less explored, and possibly warrant further research. For instance, the themes "Entrepreneurial family business" and "Leadership and top management teams" have been somewhat overlooked or have lost importance over the last years. Nonetheless, it is worth noting that some of these themes on the outer layers have grown in importance in current studies, despite not being among the top research themes. For instance, the aspects pertaining to "Small and medium enterprises" also as a result of an increasing research attention to "Family businesses".

Table 3 Top research themes by period

\begin{tabular}{|c|c|c|}
\hline 1991-2000 & $2001-2005$ & $2006-2010$ \\
\hline $\begin{array}{l}\text { 1. Corporate venturing and business } \\
\text { competition ( } 35 \text { ) }\end{array}$ & 1. Entrepreneurial process (124) & 1. Entrepreneurial process (296) \\
\hline 2. Entrepreneurial process (23) & $\begin{array}{l}\text { 2. Environmental and } \\
\text { external determinants of } \\
\text { entrepreneurship (116) }\end{array}$ & $\begin{array}{l}\text { 2. Environmental and } \\
\text { external determinants } \\
\text { of entrepreneurship (259) }\end{array}$ \\
\hline $\begin{array}{l}\text { 3. Methods, theories and } \\
\text { research issues (16) }\end{array}$ & $\begin{array}{l}\text { 3. Value creation and } \\
\text { performance }(86)\end{array}$ & $\begin{array}{l}\text { 3. Value creation and } \\
\text { performance (206) }\end{array}$ \\
\hline 4. Value creation and performance (12) & $\begin{array}{l}\text { 4. Methods, theories and } \\
\text { research issues ( } 81)\end{array}$ & $\begin{array}{l}\text { 4. Psychological, cognitive and } \\
\text { individual characteristics (204) }\end{array}$ \\
\hline 5. Industry analysis (12) & 5. Entrepreneurial resources (61) & $\begin{array}{l}\text { 5. Methods, theories and } \\
\text { research issues (195) }\end{array}$ \\
\hline $\begin{array}{l}\text { 6. Environmental and external } \\
\text { determinants of entrepreneurship (11) }\end{array}$ & $\begin{array}{l}\text { 6. Psychological, cognitive and } \\
\text { individual characteristics (56) }\end{array}$ & 6. Entrepreneurial resources (158) \\
\hline $\begin{array}{l}\text { 7. Leadership, TMT and } \\
\text { decision-making (9) }\end{array}$ & $\begin{array}{l}\text { 7. Entry modes, international, } \\
\text { Born-global and MNE (56) }\end{array}$ & $\begin{array}{l}\text { 7. Entrepreneurial networks } \\
\text { (trust and relational) (145) }\end{array}$ \\
\hline 8. High-tech entrepreneurship (8) & $\begin{array}{l}\text { 8. Entrepreneurial networks } \\
\text { (trust and relational) (54) }\end{array}$ & 8. Founders (130) \\
\hline 9. Organization (8) & 9. High-tech entrepreneurship (52) & 9. High-tech entrepreneurship (128) \\
\hline $\begin{array}{l}\text { 10. Psychological, cognitive and } \\
\text { individual characteristics (8) }\end{array}$ & 10. Founders (46) & $\begin{array}{l}\text { 10. Corporate venturing and } \\
\text { business competition (92) }\end{array}$ \\
\hline
\end{tabular}

Note: In parenthesis the keywords frequencies Source: Data collected from ISI - Web of Knowledge 


\section{Discussion}

In this study we combine three facets: an identification of the "must read" works on entrepreneurship, a structural analysis of the intellectual ties, and a longitudinal analysis of how research endeavors have shifted over time. Using objective metrics and defining a set of methodological procedures we provide an objective and unbiased account of the literature published over a period of thirty years. To the best of our knowledge this is the largest scale bibliometric studies conducted on the field and complements existing bibliometric and literature reviews (e.g., Ratnatunga and Romano 1997; Shane 2000; Cornelius et al. 2006; Schildt et al. 2006; Teixeira 2011; Meyer et al. 2012; Busenitz et al. 2014) in providing a depiction of the intellectual structure of entrepreneurship research, its knowledge foundations, core literature, theories and the topics that defined the field over the past decades. This study is thus especially useful for doctoral students and researchers newly arrived to the discipline.

\section{Brief review of the knowledge base}

Our analyses provide munificent data to examine the accumulated knowledge. A synthesis of all developments is unviable but a brief analysis based on the most cited works (Table 1), co-citation network (Fig. 2) and themes (Fig. 3 and Table 3) is interesting in summarizing the knowledge base and emphasis of research of the field.

Examining the intellectual structure Schumpeter's (1934) emerged at the core of the knowledge base, revealing the high status of Schumpeter's work to the discipline. The remaining network includes several seminal pieces of management theories, such as Stinchcombe (1965), Penrose (1959), Barney (1991), Nelson and Winter (1982) and Porter (1980) (see Fig. 2). These are evidence that the intellectual structure of entrepreneurship research shows great theoretical diversity and has used many of the mainstream management theories, such as social networks (Granovetter 1985; Aldrich and Zimmer 1986), resource dependence (Pfeffer and Salancik 1978), organizational learning (Cohen and Levinthal 1990), resource based views (Penrose 1959; Barney 1991), agency theory (Jensen and Meckling 1976), among others. The influence of a multitude of theories may be due to a lack of a broad theoretical framework which arguably makes the entrepreneurship field "rich in facts but poor in theory" (Koppl 2007, p. 4). Albeit all the theories are well intertwined in research, a possible debate is whether using other theories (Low and Macmillan 1988) diminishes the merits of the field. Gartner (2001) stated that no single theory can encompass the diversity of objects of study in entrepreneurship.

It may appear surprising that a large number of highly cited (or high impact) articles delve into the domain and raison d'être of entrepreneurship as a field (e.g., Shane and Venkataraman 2000; Schildt et al. 2006). This debate is relevant since it may shape the future of the discipline. However, examining this pool of works there is an agreement that entrepreneurship pertains to the creation of new firms (e.g., Low and MacMillan 1988; Shane and Venkataraman 2000; Gartner 2001). Nonetheless, some scholars suggest an emphasis on opportunities (identifying, evaluating and exploiting) to define entrepreneurship (Shane 2003), and move past the self-employment and firms' founders paradigms. Thus entrepreneurship research may delve a plethora of issues beyond new venture creation and include other issues such as the growth of existing firms and the role of the Top Management Teams (Shane 2003). 
We identified the diversity of objects of study (see Fig. 3). Confirming Low and MacMillan (1988) and Ratnatunga and Romano (1997) the core focus of research seems to reside on the entrepreneur and the environment, but other emphases are distinguishable such as the behavioral aspects of the entrepreneur (McClelland 1961; Busenitz and Barney 1997), entrepreneurial orientation (Miller 1983; Lumpkin and Dess 1996) and innovation generating new ventures (Gartner 1985). The diversity of objects and subjects in entrepreneurship has led Ratnatunga and Romano (1997) to compare the field to a "garbage can". It is perhaps worth debating whether such diversity differs markedly from other disciplines.

The field has also been marked by increasing concern with methodological aspects. Low and MacMillan (1988) claimed for more methodological rigor in entrepreneurship research and Chandler and Lyon (2001) showed that the discipline evolved from case studies based to growingly using sophisticated statistical techniques. In our analyses, the high citation frequency of Nunnally (1978) and Eisenhardt (1989) is probably evidence of the concern with rigor. The methodological concerns, including in statistical techniques, may help move the discipline towards a state of maturity (van Burg et al. 2013). Possibly this will entail changes in how data is collected and the types of hypotheses testing possible. For instance, greater rigor will lead to using larger sample sizes, in contrast to qualitative and case-based approaches. Other change may be in incorporating longitudinal assessments (Low and Macmillan 1988) such as in examining the evolution of new firms, international expansion, failure and success (Shane 2003).

\section{Limitations and additional research avenues}

This study has limitations. First, the limitations regarding the bibliometric method itself. We pooled our dataset from Thomson-Reuters ISI Web of Knowledge but while ISI is a good resource, it comprises only a small subset of all existing journals and leaves out other source documents such as books and dissertations. Moreover, we only included a subset of all journals in ISI, which further limits the scope of the analysis especially in an emerging field such as entrepreneurship. An additional limitation is that ISI includes almost exclusively articles written in English which may generate some bias. Hence, while our selection of journals did not seek to be exhaustive of all research, it purports to be representative of the main works that have been done in the field. Future studies may extend the sample to other journals and source documentation.

Other limitation pertains to the use of citation and co-citation data. Relying on citation and co-citation data is well established in bibliometric studies to scrutinize the intellectual structure and knowledge base of a field, but it may tend to favor older, more established, works over new contributions. Some older works have gained the status of "mandatory" references and may be cited for ceremonial reasons. That is, while citation counts are a measure of impact, without an in-depth content analysis we are not able to identify the context in which citations are made. Similarly, co-citation metrics are used to infer conceptual proximity but analyzing the ties says little about the context. Future research can complement our findings with a content analysis of the articles. 
Furthermore, using standard citation and co-citation methods does not permit uncovering emerging themes and streams of research. Bibliometric studies scrutinize the extant published research and cannot uncover new trends, emerging topics or future shifts. Nor it is possible to identify works that will likely impact the field in the future. New articles, despite how innovative, tend to have low citation counts, and hence they are not captured in bibliometric analyses that examine the higher impact (higher citation frequencies) works. However, by providing a rear view perspective, bibliometric and scientometric studies are able to expose scholars to systematized presentations of what is known and capable scholars will thus be able to draw insights into what may prove to be largely untapped knowledge areas.

We found that the main sources of knowledge have been based in the US, UK and Canada, with recent increase in Europe, consistent with previous studies (Schildt et al., 2006). These have been the core sources of knowledge reside, and may explain, at least in part, a common critique that little is known outside the US and Europe. It is possible that knowledge also develops in an idiosyncratic response to local concerns and trends (Jing et al. 2014), and future studies may observe those local specificities. Nevertheless we were unable to identify - both in the themes delved into and in the core references - if there were any specificities to these countries. For instance, perhaps in Asian countries it may prove interesting to delve into the idiosyncratic institutions and their effects on entrepreneurial activity. Conversely, in African countries it may be more interesting the understanding of an array of informal endeavors supporting entrepreneurship.

The legitimation process of the entrepreneurship field is also far from completed. Although there is some work addressing the core concerns of entrepreneurship research (e.g., Low and MacMillan 1988) additional insights are still necessary to establish the boundaries of the discipline, namely "what is not entrepreneurship" (Busenitz et al. 2003, p. 298). We found evidence to support the strong influence of other management disciplines (especially strategic management) on entrepreneurship research. Thus the permeable boundaries of the field hamper the development of entrepreneurshipspecific theories and increase the research fragmentation. Therefore establishing the boundaries of the field and developing theories which suit entrepreneurship research is a broad avenue of enquiry.

\section{Conclusions}

As a field develops scholars often feel the need to pause and make sense of the accumulated knowledge to truly understand the state of the art of the field and its progress. We followed this concern in our review of the literature. However, these are also opportunities to detect gaps, uncover areas that have been less explored, and devise a research agenda for future work. For practitioners this study also has value namely in providing a swift overview of the field and pointing the fundamental works worth reading.

A final remark to observe that albeit the questioning of whether entrepreneurship has a standing base to become a fully-fledged discipline, it is becoming evident that there a number of phenomena benefit from an entrepreneurial lens. Moreover, as the field progresses novel conceptual approaches and theories are likely to emerge to tighten the domain in a well bounded discipline. 


\section{Appendix}

Table 4 Journals included in the sample

\begin{tabular}{|c|c|c|c|c|}
\hline Journal & $\begin{array}{l}\text { Number of articles in } \\
\text { sample }\end{array}$ & $\begin{array}{l}\text { ISI Impact } \\
\text { Factor }\end{array}$ & $\begin{array}{l}\text { Scopus } \\
\text { SJR }\end{array}$ & $\begin{array}{l}\text { Scopus H } \\
\text { index }\end{array}$ \\
\hline Journal of Business Venturing & 413 & 3.062 & 2.959 & 90 \\
\hline Small Business Economics & 326 & 1.549 & 1.710 & 64 \\
\hline Journal of Small Business Management & 192 & 1.392 & 2.013 & 51 \\
\hline Entrepreneurship Theory and Practice & 177 & 2.542 & 2.373 & 57 \\
\hline $\begin{array}{l}\text { Entrepreneurship and Regional } \\
\text { Development }\end{array}$ & 120 & 0.943 & 0.835 & 45 \\
\hline International Small Business Journal & 97 & 1.492 & 0.752 & 35 \\
\hline Strategic Entrepreneurship Journal & 61 & 2.053 & - & - \\
\hline Strategic Management Journal & 88 & 3.783 & 6.148 & 166 \\
\hline Organization Studies & 48 & 2.328 & 1.943 & 80 \\
\hline Management Science & 43 & 1.733 & 3.180 & 153 \\
\hline Organization Science & 38 & 4.338 & 6.730 & 133 \\
\hline Academy of Management Journal & 37 & 5.608 & 7.729 & 182 \\
\hline Journal of International Business Studies & 37 & 3.406 & 3.653 & 108 \\
\hline Journal of Management & 33 & 4.595 & 5.096 & 114 \\
\hline $\begin{array}{l}\text { Journal of Product Innovation } \\
\text { Management }\end{array}$ & 28 & 2.109 & 2.281 & 82 \\
\hline Academy of Management Review & 22 & 6.169 & 7.963 & 163 \\
\hline Administrative Science Quarterly & 17 & 4.212 & - & - \\
\hline
\end{tabular}

Source: ISI impact factor retrieved from JCR Social Sciences Edition 2011; Scopus SJR and Scopus H-index retrieved from SCImago Journal Rank 2011. Harzing's classifications not displayed here

Table 5 Main research themes

\begin{tabular}{ll}
\hline Research themes & Frequency \\
\hline Entrepreneurial process & 443 \\
Environmental and external determinants of entrepreneurship & 386 \\
Value creation and performance & 304 \\
Methods, theories and research issues & 292 \\
Psychological, cognitive and individual characteristics & 268 \\
Entrepreneurial resources & 225 \\
Entrepreneurial networks (trust \& relational) & 205 \\
High-tech entrepreneurship & 188 \\
Founders & 179 \\
Corporate venturing and business competition & 162 \\
Industry analysis & 112 \\
Organization & 109 \\
Entry modes, international, Born-global \& MNE & 138 \\
Cultural issues & 98 \\
Leadership, TMT and decision-making & 98 \\
Small and Medium Enterprises & 91 \\
Entrepreneurial opportunity & 78 \\
Knowledge-based view & 83
\end{tabular}


Table 5 Main research themes (Continued)

\begin{tabular}{ll}
\hline Liabilities of newness \& survival of firms & 82 \\
Institutions and institutional entrepreneurship & 80 \\
Human resource management & 63 \\
Organizational decision-making & 60 \\
Entrepreneurial family business & 51 \\
Commercialization and marketing & 46 \\
Business activities & 39 \\
\hline
\end{tabular}

Note: Values are the frequency of the author-supplied keywords grouped in each major theme

\section{Competing interests}

The authors declare that they have no competing interests.

\section{Authors' contributions}

RM collected the data. MF and NR analyzed the data and wrote the article. All authors read and approved the final manuscript.

\section{Acknowledgements}

We thank the support of the ESTG - Instituto Politécnico de Leiria for conducting this research.

\section{Author details}

${ }^{1}$ School of Technology and Management, Polytechnic Institute of Leiria, Leiria, Portugal. ${ }^{2}$ Graduate School of Management, Universidade Nove de Julho, Av. Francisco Matarazzo, 612, Prédio C - 20, 05001-100 São Paulo, SP, Brazil. ${ }^{3}$ School of Technology and Management globADVANTAGE - Center of Research in International Business \& Strategy, Polytechnic Institute of Leiria, Morro do Lena - Alto Vieiro, 2411-901 Leiria, Portugal.

Received: 28 October 2014 Accepted: 4 August 2015

\section{Published online: 19 August 2015}

\section{References}

Aldrich, H. (1999). London; Thousand Oaks. CA: Sage. Organizations evolving.

Aldrich, H, \& Zimmer, C. (1986). Entrepreneurship through social networks. In D Sexton \& R Smilor (Eds.), The art and science of entrepreneurship (pp. 3-23). Cambridge, MA: Ballinger.

Alvarez, S, \& Busenitz, L. (2001). The entrepreneurship of resource-based theory. Journal of Management, 27(6), 755-775.

Alvarez, C, Urbano, D, \& Amorós, J. (2012). GEM research: achievements and challenges. Small Business Economics, 42, 445-465.

Audretsch, D, \& Feldman, M. (1996). R\&D spillovers and the geography of innovation and production. American Economic Review, 86(3), 630-640.

Barney, J. (1991). Firm resources and sustained competitive advantage. Journal of Management, 17(1), 99-120.

Bergmann, H, Mueller, S, \& Schrettle, T. (2013). The use of global entrepreneurship monitor data in academic research: A critical inventory and future potentials. International Journal of Entrepreneurial Venturing, 6(3), 242-276.

Birch, D. (1987). Job creation in America: How our smallest companies put the most people to work. New York, NY: Free Press. Bornmann, L, \& Daniel, H. (2008). What do citation counts measure? A review of studies on citing behavior. Journal of Documentation, 64(1), 45-80.

Broadus, R. (1987). Towards a definition of "bibliometrics". Scientometrics, 12(5), 373-379.

Brockhaus, R. (1982). The psychology of the entrepreneur. In C Kent, D Sexton, \& K Vesper (Eds.), Encyclopedia of entrepreneurship (pp. 39-57). Englewood Cliffs, NJ: Prentice-Hall.

Burt, R. (1992). Structural holes: The social structure of competition. Boston, MA: Harvard University Press.

Busenitz, L, \& Barney, J. (1997). Differences between entrepreneurs and managers in large organizations: Biases and heuristics in strategic decision-making. Journal of Business Venturing, 12(1), 9-30.

Busenitz, L, West, G, Shepherd, D, Nelson, T, Chandler, G, \& Zacharakis, A. (2003). Entrepreneurship research in emergence: Past trends and future directions. Journal of Management, 29(3), 285-308.

Busenitz, L, Plummer, L, Klotz, A, Shahzad, A, \& Rhoads, K. (2014). Entrepreneurship research (1985-2009) and the emergence of opportunities. Entrepreneurship: Theory and Practice, 38(5), 981-1000.

Campbell, N, \& Mitchell, D. (2012). A (partial) review of entrepreneurship literature across disciplines. Journal of Entrepreneurship and Public Policy, 1(2), 183-199.

Chandler, A. (1962). Strategy and structure. Cambridge, MA: MIT Press.

Chandler, G, \& Lyon, D. (2001). Issues of research design and construct measurement in entrepreneurship research: The past decade. Entrepreneurship: Theory and Practice, 25(4), 101-113.

Churchill, N, \& Lewis, V. (1986). Entrepreneurship research: directions and methods. In D Sexton \& R Smilor (Eds.), The Art and Science of Entrepreneurship (pp. 333-365). Cambridge, MA: Ballinger.

Cohen, W, \& Levinthal, D. (1990). Absorptive capacity: A new perspective on learning and innovation. Administrative Science Quarterly, 35(1), 128-152

Cornelius, B, Landström, H, \& Persson, O. (2006). Entrepreneurial studies: The dynamic research front of a developing social science. Entrepreneurship: Theory and Practice, 30(3), 375-398.

Culnan, M. (1987). Mapping the intellectual structure of MIS, 1980-1985: A co-citation analysis. MIS Quarterly, 11(3), 341-353. 
Cyert, R, \& March, J. (1963). A behavioral theory of the firm. Englewood Cliffs, NJ: Prentice-Hall.

Eisenhardt, K. (1989). Building theories from case study research. Academy of Management Review, 14(4), 532-550.

Eisenhardt, K, \& Schoonhoven, C. (1990). Organizational growth: Linking founding team, strategy, environment, and growth among U.S. semiconductor ventures. Administrative Science Quarterly, 35(3), 504-529.

Evans, D, \& Jovanovic, B. (1989). An estimated model of entrepreneurial choice under liquidity constraints. Journal of Political Economy, 97(4), 808-827.

Ferreira, M, Santos, J, Almeida, M, \& Reis, N. (2014). Mergers \& acquisitions research: A bibliometric study of top strategy and international business journals, 1980-2010. Journal of Business Research, 67(12), 2550-2558.

Furrer, O, Tomas, H, \& Goussevskaia, A. (2008). The structure and evolution of the strategic management field: A content analysis of 26 years of strategic management research. International Journal of Management Reviews, 10(1), 1-23.

Garfield, E. (1979). Is citation analysis a legitimate evaluation tool? Scientometrics, 1(4), 359-375.

Gartner, W. (1985). A conceptual framework for describing the phenomenon of new venture creation. Academy of Management Review, 10(4), 696-706.

Gartner, W. (2001). Is there an elephant in entrepreneurship? Blind assumptions in theory development. Entrepreneurship: Theory and Practice, 25(4), 27-39.

Granovetter, M. (1985). Economic action and social structure: The problem of embeddedness. American Journal of Sociology, 91(11), 481-510

Harzing, A. (2011) Journal quality list (Fourty-first Edition). Unpublished ranking, available at www.harzing.com/jgl.htm

Jensen, M, \& Meckling, W. (1976). Theory of the firm: Managerial behavior, agency costs and ownership structure. Journal of Financial Economics, 3(4), 305-360.

Jing, S, Qinghua, Z, Landström, H. (2014). Entrepreneurship research in three regions-the USA, Europe and China. International Entrepreneurship and Management Journal, (ahead-of-print).

Kent, C, Sexton, D, \& Vesper, K. (1982). Encyclopedia of entrepreneurship. Englewood Cliffs, NJ: Prentice-Hall.

Kirzner, I. (1973). Competition and entrepreneurship. Chicago, IL: University of Chicago Press.

Knight, F. (1921). Risk, uncertainty and profit. New York, NY: Harper.

Koppl, R. (2007). Entrepreneurial behavior as a human universal. In M Minniti (Ed.), Entrepreneurship: The engine of growth (pp. 1-20). Westport, CT: Praeger Publishers.

Landström, H, Harirchi, G, \& Åström, F. (2012). Entrepreneurship: Exploring the knowledge base. Research Policy, 41(7), 1154-1181.

Low, M, \& MacMillan, I. (1988). Entrepreneurship: Past research and future challenges. Journal of Management, 14(2), 139-161.

Lumpkin, G, \& Dess, G. (1996). Clarifying the entrepreneurial orientation construct and linking it to performance. Academy of Management Review, 21(1), 135-172.

McClelland, D. (1961). The achieving society. Princeton, NJ: Van Nostrand.

McDougall, P, \& Oviatt, B. (2000). International entrepreneurship: The intersection of two research paths. Academy of Management Journal, 43(5), 902-906.

Meyer, M, Libaers, D, Thijs, B, Grant, K, Glänzel, W, \& Debackere, K. (2012). Origin and emergence of entrepreneurship as a research field. Scientometrics, 98(1), 1-13.

Miles, R, \& Snow, C. (1978). Organizational strategy, structure and process. New York, NY: McGraw-Hill.

Miller, D. (1983). The correlates of entrepreneurship in three types of firms. Management Science, 29(7), 770-791.

Mintzberg, H. (1979). The structuring of organizations. Englewood Cliffs, NJ: Prentice-Hall.

Nelson, R, \& Winter, S. (1982). An evolutionary theory of economic change. Boston, MA: Harvard University Press.

Neumark, D, Wall, B, \& Zhang, J. (2011). Do small businesses create more jobs? New evidence for the United States from the National Establishment Time Series. Review of Economics and Statistics, 93(1), 16-29.

Nunnally, J. (1978). Psychometric theory. New York, NY: McGraw Hill.

Oviatt, B, \& McDougall, P. (1994). Toward a theory of international new ventures. Journal of International Business Studies, 25(1), 45-64.

Oviatt, B, \& McDougall, P. (2005). Defining international entrepreneurship and modeling the speed of internationalization. Entrepreneurship: Theory and Practice, 29(5), 537-554.

Penrose, E. (1959). The theory of the growth of the firm. New York, NY: John Wiley.

Pfeffer, J, \& Salancik, G. (1978). The external control of organizations: A resource dependence perspective. New York, NY: Harper \& Row.

Pinchot, G, III. (1985). Intrapreneuring. New York, NY: Harper \& Row.

Ponzi, L. (2002). The intellectual structure and interdisciplinary breadth of Knowledge Management: A bibliometric study of its early stage of development. Scientometrics, 55(2), 259-272.

Porter, M. (1980). Competitive strategy. New York, NY: Free Press.

Ratnatunga, J, \& Romano, C. (1997). A 'citation classics' analysis of articles in contemporary small enterprise research. Journal of Business Venturing, 12(3), 197-212.

Reynolds, P. (2005). Understanding business creation: Serendipity and scope in two decades of business creation studies. Small Business Economics, 24(4), 359-364.

Schildt, H, Zahra, S, \& Sillanpaa, A. (2006). Scholarly communities in entrepreneurship research: A co-citation analysis. Entrepreneurship: Theory and Practice, 30(3), 399-415.

Schumpeter, J. (1934). The theory of economic development. Cambridge, MA: Harvard University Press.

Shane, S. (2000). Prior knowledge and the discovery of entrepreneurial opportunities. Organizational Science, 11(4), $448-469$.

Shane, S. (2003). A general theory of entrepreneurship. Cheltenham: Edward Elgar.

Shane, S, \& Venkataraman, S. (2000). The promise of entrepreneurship as a field of research. Academy of Management Review, 25(1), 217-226

Short, J, Ketchen, D, Shook, C, \& Ireland, R. (2010). The concept of "opportunity" in entrepreneurship research: Past accomplishments and future challenges. Journal of Management, 36(1), 40-65.

Stinchcombe, A. (1965). Social structure and organizations. In J March (Ed.), Handbook of Organizations (pp. 142-193). Chicago, IL: Rand McNally. 
Tahai, A, \& Meyer, M. (1999). A revealed preference study of management journals' direct influences. Strategic Management Journal, 20, 279-296.

Teixeira, A. (2011). Mapping the (in)visible college(s) in the field of entrepreneurship. Scientometrics, 89(1), 1-36. van Burg, E, Gilsing, V, Reymen, I, \& Romme, A. (2013). The formation of fairness perceptions in the cooperation between entrepreneurs and universities. Journal of Product Innovation Management, 30(4), 677-694.

van Burg, E, \& Romme, G. (2014). Creating the future together: Toward a framework for research synthesis in entrepreneurship. Entrepreneurship: Theory and Practice, 38(2), 369-397.

Venkataraman, S. (1997). The distinctive domain of entrepreneurship research. In J Katz (Ed.), Advances in entrepreneurship, firm emergence and growth (pp. 119-138). Greenwich, CT: JAI Press.

Vesper, K. (1990). New venture strategies. Englewood Cliffs, NJ: Prentice Hall.

White, H, \& Griffith, B. (1981). Author co-citation: A literature measure of intellectual structure. Journal of the American Society for Information Science, 32(3), 163-171.

White, D, \& McCain, K. (1998). Visualizing a discipline: An author co-citation analysis of information science, 1972-1995. Journal of the American Society for Information Science, 49(4), 327-355.

Wilken, P. (1979). Entrepreneurship: A comparative and historical study. Norwood, NJ: Alex.

Williamson, O. (1975). Markets and hierarchies: Analysis and antitrust implications. New York, NY: Free Press.

Zahra, S. (2005). A theory of international new ventures: A decade of research. Journal of International Business Studies, 36(1), 20-28.

Zahra, S, \& Covin, J. (1995). Contextual influences on the corporate entrepreneurship-performance relationship: A longitudinal analysis. Journal of Business Venturing, 10(1), 43-58.

\section{Submit your manuscript to a SpringerOpen ${ }^{\circ}$} journal and benefit from:

- Convenient online submission

- Rigorous peer review

- Immediate publication on acceptance

- Open access: articles freely available online

- High visibility within the field

- Retaining the copyright to your article 